\title{
PEMBIASAAN KETERAMPILAN BERPIKIR KRITIS \\ SEBAGAI SARANA IMPLEMENTASI SIKAP SPIRITUAL \\ DALAM PEMBELAJARAN IPA \\ TINGKAT SEKOLAH DASAR
}

\author{
Izzatin Kamala \\ Program Studi Pendidikan Guru Madrasah Ibtidaiyah \\ UIN Sunan Kalijaga \\ Email: izaatinkamala@gmail.com
}

\begin{abstract}
ABSTRAK
Tujuan penelitian ini adalah mengungkapkan penerapan paradigma integrasi-interkoneksi untuk pengembangan Kompetensi Dasar sikap spiritual bagi peserta didik pada materi IPA Sekolah Dasar Kelas 6, dan untuk mengungkapkan pemanfaatan keterampilan berpikir kritis sebagai salah satu keterampilan abad 21 untuk penempaan Kompetensi Dasar sikap spiritual bagi peserta didik pada Siswa Kelas 6 di Sekolah Dasar Islam Terpadu Sunan Averroes. Penelitian ini menggunakan pendekatan kualitatif, dengan memanfaatkan wawancara mendalam, observasi, dan dokumentasi sebagai metode pengumpulan datanya. Fokus kajian penelitian ini adalah penggunaan keterampilan Abad 21 sebagai sarana implementasi sikap spiritual dalam pembelajaran IPA. Temuan penelitian ini menunjukkan bahwa SDIT Sunan Averroes berhasil mengembangkan Kompetensi Dasar sikap spiritual dalam materi IPA Kelas 6 Semester 2 dengan mengembangkan paradigma keilmuan integrasi-interkoneksi serta didukung semangat sejarah penamaan SDIT Sunan Averroes itu sendiri. Strategi penggunaan keterampilan Abad 21 sebagai sarana implementasi sikap spiritual dalam pembelajaran IPA Kelas 6 adalah dengan cara menyisipkan pertanyaan siapakah Pencipta dari segala eksistensi dan peristiwa alam tersebut. Dengan menanya Pencipta, guru sedang mengasah salah satu ketrampilan Abad 21, yakni critical thinking.
\end{abstract}

Kata Kunci: Berpikir Kritis, Ilmu Pengetahuan Alam (IPA), Integrasi-Interkoneksi, Keterampilan Abad 21, Sikap Spiritual. 


\section{ABSTRACT}

The purpose of this research is to reveal the application of the integration-interconnection paradigm for the development of basic competencies in spiritual attitudes for students in Class 6 Elementary School Science materials, and to express the use of critical thinking skills as one of the 21st century skills for forging Basic Competencies spiritual attitudes for Class students 6 in the Integrated Islamic Elementary School of Sunan Averroes. This study uses a qualitative approach, by utilizing in-depth interviews, observations, and documentation as a method of data collection. The focus of this research study is the use of 21st Century skills as a means of implementing spiritual attitudes in science learning. The findings of this study indicate that ES of Sunan Averroes (ESSA) succeeded in developing the basic competency of spiritual attitudes in the material of Grade 6 Semester 2 science by developing the scientific paradigm of integration and supported by the historical spirit of naming ESSA itself. The strategy for using 21st Century skills as a means of implementing spiritual attitudes in Class 6 science learning is by inserting the question of who is the Creator of all these natural existence and events. By asking the Creator, the teacher is honing one of the 21st Century skills, which is critical thinking.

Keywords: Critical Thinking, Natural Sciences (IPA), Integration-Interconnection, 21st Century Skills, Spiritual Attitudes.

\section{A. PENDAhULUAN}

Regulasi pemberlakuan kurikulum 2013 (K-13) di Indonesia telah mengalami dinamika perubahan yang signifikan. Dinamika regulasinya mengalami perubahan dengan keluarnya beberapa Peraturan Menteri Pendidikan dan Kebudayaan (Permendikbud) selama beberapa tahun mulai dari 2013 sampai 2018. Dari beberapa regulasi dalam paket Permendikbud, regulasi 
yang menarik untuk disoroti berkaitan dengan pemanfaatan keterampilan Abad 21 sebagai sarana implementasi sikap spiritual dalam pembelajaran Ilmu Pengetahuan Alam (IPA) pada sekolah dasar adalah Permendikbud tentang KI-KD, yakni Permendikbud Nomor 67 tahun 2013 tentang KD dan Struktur Kurikulum SD-MI, Permendikbud Nomor 24 Tahun 2016 tentang Kompetensi Inti dan Kompetensi Dasar Pelajaran pada Kurikulum 2013 pada Pendidikan Dasar dan Pendidikan Menengah, dan Permendikbud Nomor 37 Tahun 2018 Tentang Perubahan Atas Permendikbud Nomor 24 Tahun 2016 Tentang Kompetensi Inti dan Kompetensi Dasar Pelajaran pada Kurikulum 2013 pada Pendidikan Dasar dan Pendidikan Menengah. ${ }^{1}$

Dinamisnya perubahan regulasi pelaksanaan K-13 tersebut, sebenarnya dilatarbelakangi keinginan merespon tantangan zaman. Salah satunya adalah kebutuhan mengejar keterampilan Abad 21. Tantangan Abad 21 ditandai dengan melimpahnya teknologi informasi. Dengan masifnya arus teknologi dan informasi di Abad 21 ini, di satu sisi tentunya membawa manfaat bagi kehidupan manusia, tetapi di sisi lain bisa saja membawa petaka bagi kemanusiaan apabila tidak bisa dikelola secara arif. Dalam kasus negatifnya, derasnya arus penggunaan internet dan fasilitas dunia maya lainnya telah mengancam kesantunan bahkan moralitas

\footnotetext{
1 Menteri Pendidikan dan Kebudayaan Republik Indonesia, Perubahan Atas Permendikbud Nomor 24 Tahun 2016 Tentang Kompetensi Inti Dan Kompetensi Dasar Pelajaran Pada Kurikulum 2013 Pada Pendidikan Dasar Dan Pendidikan Menengah, Peraturan Menteri Pendidikan dan Kebudayaan Republik Indonesia No. 37 Tahun 2018, Ditetapkan 14 Desember 2018.

2 I Wayan Redhana, "Mengembangkan Keterampilan Abad Ke-21 Dalam Pembelajaran Kimia”, Jurnal Inovasi Pendidikan Kimia, Vol 13, No 1, 2019, halaman 2239-2253, hlm. 2240-2241.
} 
generasi anak. Ini terbukti dengan banyaknya kasus perkosaan, pencurian, perkelahian, pembunuhan, konsumsi narkotika dan tindak pidana lainnya yang pelakunya melibatkan anak di bawah umur. Ini seharusnya tidak mesti terjadi karena sistem dan kurikulum pendidikan nasional sebenarnya didesain semakin bagus.

Kalau praktik negatif generasi anak masih terjadi, ini artinya kehadiran limpahan teknologi-informasi Abad 21 perlu dikelola dengan keterampilan yang bijak. Adanya kenakalan anak berbasis teknologi informasi menunjukkan adanya ketidaksinambungan antara penempaan kompetensi pengetahuan dengan penempaan kompetensi spiritual peserta didik. Keharusan merevitalisasi kompetensi dasar sikap spiritual ini termasuk menjadi tantangan dalam Pembelajaran IPA pada tingkat sekolah dasar. Sebagai diskusi, pada tahun 2013, Permendikbud 67/2013 mengatur tentang kompetensi inti dan kompetensi dasar atas kompetensi sikap spiritual bagi materi IPA Kelas VI. Selanjutnya, Permendikbud 24/2016 masih mempertahankan kompetensi inti dari kompetensi kompetensi sikap spiritual pada materi IPA Kelas VI, tetapi regulasi Permendikbud tersebut telah menghapus kompetensi dasarnya. Pada Tahun 2018, walaupun terdapat regulasi baru berupa Permendikbud Nomor 37 Tahun 2018, tetapi regulasi yang baru tersebut tidak mengembalikan uraian kompetensi dasar dari kompetensi sikap spiritual. Regulasi yang baru tersebut hanya membahas mengenai penambahan materi tentang informatika mulai dari SMP sampai SMA dan SMK. 
Eksistensi sikap spiritual dalam materi IPA Kelas VI merupakan hal yang penting. Walaupun IPA merupakan mata pelajaran 'sekuler', pada pendidikan tingkat sekolah dasar, materinya justru menjadi sarana memperkenalkan penguasaan teknologi informasi sebagai kebutuhan keterampilan Abad 21. Menyikapi ketiadaan uraian kompetensi dasar atas sikap spiritual (KD sikap spiritual) sebagaimana tersebut di atas, guru harus mengembangkan kreativitas dan kemandiriannya untuk merumuskan kompetensi sikap spiritual sesuai dengan karakteristik yang dihadapinya. Walaupun penjabaran atas KD sikap spiritual tidak ditemukan dalam regulasi utama, setiap guru harus bisa mengembangkannya baik secara eksplisit maupun implisit dalam setiap Rencana Pelaksanaan Pembelajaran (RPP).

Tantangan melakukan inovasi ini menjadi semakin niscaya bagi sekolah dasar yang berbasis keagamaan. Sebagai contohnya adalah Sekolah Dasar Islam Terpadu Sunan Averroes (SDIT Sunan Averroes). Sebagai sekolah dasar yang mengusung semangat keislaman, stakeholders sekolah tentunya ingin menyampaikan pengetahuan kepada peserta didik dengan bernafaskan ajaran Islam. Selain semangat keislaman, dengan menggunakan nama “Terpadu”, sekolah ini juga tidak ingin ketinggalan dalam bidang penguasaan eksperimental scientis sebagaimana menjadi keniscayaan dalam keterampilan Abad 21. Peneliti telah melakukan penelitian di SDIT Sunan Averroes, yang tepatnya di Kelas 6 Semester II Tahun Akademik 2018/2019 dengan fokus tentang inovasi guru untuk menggunakan ketrampilan Abad 21 sebagai sarana 
implementasi sikap spiritual dalam pemebelajaran IPA pada Kelas 6 Semester II sesuai regulasi K-13.

Salah satu faktor yang berpengaruh atas kemampuan adaptasi dan pengembangan inovasi yang didasari pemberlakuan regulasi kurikulum tersebut, yakni kemampuan berfikir guru. Di antara faktor yang turut mengawal kemampuan tersebut adalah paradigma guru tersebut dalam melihat realita pergulatan perkembangan pengetahuan dan tantangan zaman. Paradigma pemikiran yang dimaksud adalah paradigma integrasi-interkoneksi. Walaupun awalnya paradigma ini merupakan paradigma pengembangan keilmuan di perguruan tinggi, paradigma ini juga bisa dikembangkan sebagai cara pandang untuk merumuskan proses pembelajaran kepada peserta didik mulai tingkat dasar sampai tingkat tinggi.

Merujuk kepada paparan di atas, rumusan masalah dalam penelitian ini adalah bagaimana SDIT Sunan Averroes menerapkan paradigma integrasi-interkoneksi untuk mengembangkan KD sikap spiritual bagi peserta didik pada materi IPA Kelas VI Semester II? Bagaimana SDIT Sunan Averroes memanfaatkan pengembangan keterampilan Abad 21 sebagai penempaan KD sikap spiritual bagi peserta didik dalam bentuk RPP materi IPA Kelas VI Semester II?

Berdasarkan rumusan masalah tersebut, penelitian ini ditujukan untuk mengurai strategi SDIT Sunan Averoes menjaga kompetensi dasar sikap spiritual di tengah ketiadaan regulasi Permendikbud mengatur uraiannya. Strategi ini juga berfungsi untuk melihat kemampuan sekolah tersebut menerapkan paradigma integrasi-interkoneksi dalam mengurai problematika yang dihadapi 
penerapan K-13 di tengah keharusan menjaga kompetensi spiritual di satu sisi tetapi di sisi lain tidak menyebutkan uraiannya dalam regulasinya. Selain itu, penelitian ini juga menjadi kontribusi penting bahwa Keterampilan Abad 21 jika dikelola secara bijak bukan justru mengancam kepatuhan peserta didik terhadap ajaran agamanya, tetapi justru mendekatkan kepatuhan kepada ajaran agamanya.

\section{B. METODE PENELITIAN}

Penelitian ini menggunakan pendekatan kualitatif karena data yang dikumpulkan dalam penelitian ini bersifat kualitatif, yakni berbentuk kata dan cerita. ${ }^{3}$ Teknik pengumpulan data dilakukan melalui wawancara dan dokumentasi. Adapun wawancara yang digunakan adalah wawancara terstruktur, yakni kepada Guru Kelas 6 SDIT Sunan Averroes dan Pengurus Yayasan. Adapun metode dokumentasi digunakan untuk memperoleh data yang telah terdokumentasikan. Proses analisis datanya meliputi tiga tahap, yakni reduksi data (proses pemilihan, pemusatan perhatian pada penyederhanaan, pengabstrakan dan transformasi data kasar), penyajian data, dan penarikan kesimpulan. ${ }^{4}$

Sementara itu, beberapa teori yang digunakan sebagai pisau analisis dalam penelitian ini meliputi: regulasi kurikulum 2013 dan Kompetensi Dasar Sikap Spiritual dalam Ilmu Pengetahuan Alam,

\footnotetext{
3 Sugiyono, Metode Penelitian Kuantitatif dan Kualitatif (Bandung: Alfabeta, 2009), hlm. 9.

${ }^{4}$ Metthew B Miles dan A Michael Huberman, Analisis Data Kualitatif. Buku Sumber tentang Metode-Metode Baru, Terj.Tjetjep Rohendi Rohidi, (Jakarta: UI Press, 1992), hlm. 17-20.
} 
paradigma integrasi-interkoneksi, keterampilan abad 21 dan kurikulum 2013.

\section{Regulasi Kurikulum 2013 dan KD Sikap Spiritual dalam IPA}

Penelitian ini tidak hanya berlandaskan kepada konsep mengenai kurikulum, tetapi gabungan dari regulasi dan kurikulum. Berbicara mengenai regulasi di Indonesia, berarti kita harus mengetahui hirarki peraturan perundang-undangan di Indonesia. Sebagai negara hukum, segala hal yang diperintahkan pemberlakuannya oleh negara kepada warga negara, itu semua harus mempunyai landasan hukum positif. Termasuk dalam hal ini adalah pemberlakuan kurikulum. Sebagai kebijakan pemerintah yang diperintahkan kepada semua lembaga pendidikan dasar dan menengah (sebagai representasi warga negara) untuk melaksanakannya, K-13 mempunyai dasar regulasi berupa Permendikbud.

Secara hirarkis, sebenarnya Peraturan Menteri tidak ditemukan masuk dalam jenis dan hirarki peraturan perundangundangan. Dalam Pasal 7 Ayat (1) Undang-Undang Nomor 12 Tahun 2011 tentang Pembentukan Peraturan Perundang-undangan, jenis dan hirarki peraturan perundang-undangan adalah sebagai berikut: Undang-Undang Dasar Negara Republik Indonesia Tahun 1945, Ketetapan Majelis Permusyawaratan Rakyat, UndangUndang/Peraturan Pemerintah Pengganti Undang-Undang, Peraturan Pemerintah, Peraturan Presiden, Peraturan Daerah Provinsi, dan Peraturan Daerah Kabupaten/Kota. Walaupun tidak terdapat dalam hirarki, pada dasarnya Peraturan Menteri tetap 
merupakan sumber hukum nasional yang sah karena pada dasarnya menteri tersebut dengan kewenangannya sedang melaksanakan kewenangan untuk membantu Presiden dalam rangka penyelenggaraan urusan tertentu dalam pemerintahan dan penyelenggaraan urusan tertentu pemerintahan sesuai dengan ketentuan Peraturan Perundang-undangan ${ }^{5}$. Posisi Peraturan Menteri tersebut bisa dikatakan sebagai pelaksana peraturan pemerintah atau peraturan presiden dan sekaligus sebagai pelaksana dari peraturan-peraturan sebelumnya.

Dalam mengeluarkan paket kebijakan kurikulum di setiap masanya, pemerintah mengeluarkan beberapa peraturan menteri. Pada tahun 2013, untuk mengawali pelaksanaan kurikulum 2013, pemerintah mengeluarkan Permendikbud Nomor 54 tahun 2013 tentang Standar Kompetensi Lulusan, Permendikbud Nomor 65 tahun 2013 tentang Standar Proses, Permendikbud Nomor 66 tahun 2013 tentang Standar Penilaian, Permendikbud Nomor 67 tahun 2013 tentang KD dan Struktur Kurikulum SD/MI, Permendikbud Nomor 68 tahun 2013 tentang KD dan Struktur Kurikulum SMP/MTs, Permendikbud Nomor 69 tahun 2013 tentang KD dan Struktur Kurikulum SMA/MA, Permendikbud Nomor 70 tentang Kerangka Dasar dan Struktur Kurikulum SMK/MAK, Permendikbud Nomor 71 tahun 2013 tentang Buku Teks Pelajaran, dan Permendikbud Nomor 64 tahun 2013 tentang Standar Isi.

Sebagai perbaikan atas pelaksanaan K-13 pada tahun sebelumnya, pada tahun 2016, pemerintah mengeluarkan

${ }^{5}$ H.A.S. Natabaya, Sistem Peraturan Perundang-Undangan Indonesia (Jakarta: Sekretariat Jendral Mahkamah Konstitusi, 2006). 
Permendikbud Nomor 20 Tahun 2016 tentang Standar Kompetensi Lulusan Pendidikan Dasar dan Menengah sebagai pengganti Permendikbud 54/2013, Permendikbud Nomor 21 Tahun 2016 tentang Standar Isi Pendidikan Dasar dan Menengah sebagai pengganti Permendikbud Nomor 64 tahun 2013, Permendikbud Nomor 22 Tahun 2016 tentang Standar Proses Pendidikan Dasar dan Menengah sebagai pengganti Permendikbud Nomor 65 Tahun 2013, Permendikbud Nomor 24 Tahun 2016 tentang Kompetensi Inti dan Kompetensi Dasar sebagai pengganti Permendikbud Nomor 67/2013.

Kemudian sebagai penyempurnaan pelaksanaan K-13, pada tahun 2018, Pemerintah melakukan revisi penyempurnaan melalui beberapa regulasi berikut ini: Permendikbud Nomor 34 Tahun 2018 Tentang Standar Nasional Pendidikan Sekolah Menengah Kejuruan/Madrasah Aliyah Kejuruan; Permendikbud Nomor 35 Tahun 2018 Tentang Perubahan atas Permendikbud 58 Tahun 2014 Tentang Kurikulum 2013 Sekolah Menengah Pertama/Madrasah Tsanawiyah; Permendikbud Nomor 36 Tahun 2018 Tentang Perubahan Atas Permendikbud Nomor 59 Tahun 2014 Tentang Kurikulum 2013 Sekolah Menengah Atas/Madrasah Aliyah; dan Permendikbud Nomor 37 Tahun 2018 Tentang Perubahan atas Permendikbud Nomor 24 Tahun 2016 Tentang Kompetensi Inti dan Kompetensi Dasar Pelajaran pada Kurikulum 2013 pada Pendidikan Dasar dan Pendidikan Menengah.

Dari beberapa Permendikbud tersebut, kajian mengenai kompetensi inti-kompetensi dasar terutama atas KD sikap spiritual IPA bisa difokuskan kepada Permendikbud mengenai KI-KD. 
Permendikbud Nomor 67 tahun 2013 tentang KD dan Struktur Kurikulum SD/MI menyatakan bahwa kompetensi inti atas kompetensi sikap spiritual adalah menerima, menjalankan, dan menghargai ajaran agama yang dianutnya. Sedangkan KD sikap spiritualnya adalah bertambah keimanannya dengan menyadari hubungan keteraturan dan kompleksitas alam dan jagad raya terhadap kebesaran Tuhan yang menciptakannya, serta mewujudkannya dalam pengamalan ajaran agama yang dianutnya. Permendikbud Nomor 24 Tahun 2016 sebagai pengganti Permendikbud Nomor 67/2013 menyatakan uraian kompetensi inti sikap spiritualnya sama dengan Permendikbud sebelumnya. Namun, Permendikbud ini tidak memperinci kompetensi dasarnya. Permendikbud Nomor 37 Tahun 2018 juga melakukan hal yang sama. Alasan mengapa nilai spiritual dalam cakupan materi, kegiatan bahkan penilaiannya tidak dimunculkan redaksi eksplisitnya adalah dikarenakan kompetensi spiritual tidak dalam konteks diajarkan, tetapi untuk diimplementasikan atau diwujudkan dalam tindakan nyata peserta didik. ${ }^{6}$

Itulah sebabnya Permendikbud 22/2016 memberikan tambahan mengenai ketentuan peran guru dalam pengelolaan kelas, yang tidak hanya berkaitan pengelolaan kelas tetapi juga pengelolaan laboratorium. Sesuai dengan amanah pencapaian kompetensi sikap spiritual dan sosial, maka kegiatan pembelajaran merupakan bagian dari laboratorium menguji dua kompetensi tersebut. Oleh sebab itu, dalam memastikan pencapaian kompetensi

6 Kunandar, Penilaian Autentik (Penilaian Hasil belajar Peserta Didik berdasarkan Kurikulum 2013) (Jakarta, Indonesia: PT. Raja Grafindo Persada, 2014), hlm. 105. 
spiritual, guru berkewajiban menjadi teladan yang baik bagi peserta didik dalam menghayati dan mengamalkan ajaran agama yang dianutnya serta mewujudkan kerukunan dalam kehidupan bersama. Dalam hal sosial, guru berkewajiban menjadi teladan bagi peserta didik dalam menghayati dan mengamalkan perilaku jujur, disiplin, tanggung jawab, peduli (gotong royong, kerja sama, toleran, damai), santun, responsif dan proaktif dalam berinteraksi secara efektif dengan lingkungan sosial dan alam serta dalam menempatkan diri sebagai cerminan bangsa dalam pergaulan dunia.

Di sinilah peluang dan tantangan yang dimaksud dalam penelitian, yakni ketiadaan patokan $\mathrm{KD}$ sikap spiritual dalam Permendikbud tersebut. Kondisi ini bisa merangsang kreativitas guru untuk merumuskannya sendiri. Tetapi yang perlu dikhawatirkan juga adalah keadaan ini bisa saja justru menyebabkan guru menjadi mengabaikan kompetensi tersebut. Alasan mengapa ketiadaan eksplisitasi KD sikap spiritual dalam regulasi patut dipermasalahkan adalah berangkat dari landasan berlakunya K-13 itu sendiri. Setidaknya selama ini, dalam berbagai latar belakang regulasinya, beberapa Permendikbud selalu mengatakan bahwa kelahiran K-13 tersebut dilandasi dengan tiga landasan, yakni yuridis, teoritis dan filosofis.

Di antara landasan yuridis sudah disebutkan dalam bentuk beberapa Permendikbud di atas, dan juga bisa ditambah UUD 1945, Undang-Undang, Peraturan Pemerintah dan Peraturan Presiden. Sementara secara teoritisnya, landasan pemberlakuan K13 berangkat dari teori bahwa pelaksanaan pendidikan harus berdasarkan standar (standard-based education) dan penyusunan 
kurikulum harus berdasarkan (competency-based curriculum). Istilah standard-based education ini telah ditransformasikan dalam bentuk regulasi pemerintah melalui beberapa Permendikbud di atas. Itulah sebabnya beberapa Permendikbud tersebut mempunyai nama khusus seperti Permendikbud yang khusus mengatur tentang standar isi, standar proses, standar kompetensi lulusan, standar pendidik dan tenaga kependidikan, standar sarana dan prasarana, standar pengelolaan, standar pembiayaan, dan standar penilaian pendidikan. Pengaturan ini dimaksudkan untuk memastikan semua peserta didik yang menjalani pendidikan di setiap levelnya memiliki kualitas minimal warganegara yang telah dirinci sesuai dengan beberapa ketentuan di atas. Sementara itu, istilah competency-based curriculum meniscayakan proses belajar harus dirancang untuk memberikan pengalaman belajar seluas-luasnya bagi peserta didik dalam mengembangkan kemampuan untuk bersikap, berpengetahuan dan berketerampilan. ${ }^{7}$

Terkhusus mengenai sikap, satu kompetensi ini terdiri dari sikap spiritual dan sikap sosial. Jika dihubungkan dengan konsep kurikulum berbasis kompetensi, ini artinya semua materi dan proses pembelajaran di kelas harus mengarahkan peserta didik harus mempunyai keempat kompetensi tersebut sekaligus. Dengan demikian, setiap materi harus memandang empat kompetensi tersebut sebagai target yang integralistik. Penerapan model pembelajaran tematik-integratif sebagai pendekatan dalam pembelajaran pada K-13 menunjukkan adanya proses pembelajaran

7 Kementerian Pendidikan dan Kebudayaan, Permendikbud Nomor 67 tahun 2013 tentang KD dan Struktur Kurikulum SD-MI (Jakarta: Kementerian Pendidikan dan Kebudayaan, 2013), hlm. 4-6. 
yang berupaya mengintegrasikan berbagai kompetensi ke dalam tema tertentu. ${ }^{8}$ Keempat kompetensi tersebut harus diperoleh setiap siswa pada setiap materi dalam satu tema. Inilah sebabnya, penelitian ini mempersoalkan ketiadaan uraian KD sikap spiritual. Dengan demikian, upaya untuk melakukan inovasi perumusan KD sikap spiritual merupakan upaya untuk mengawal landasan teoretis di atas.

\section{Paradigma Integrasi Interkoneksi Bagi Kurikulum 2013}

Dalam bahasa sederhananya, istilah integrasi berasal dari kata kerja berbahasa Inggris to integrate yang artinya adalah "to join to something else so as to form a whole" (menggabungkan kepada sesuatu yang lain sehingga terciptalah keterpaduan/keseluruhan). ${ }^{9}$ Istilah integrasi ilmu pengetahuan berarti menggabungkan beberapa disiplin ilmu menjadi satu. Sementara itu, istilah paradigma bisa dimaknai sebagai sekumpulan anggapan tentang bagaimana seseorang melihat, memahami dan menerima fenomena. Suatu paradigma digunakan seseorang untuk memecah/memilah kompleksitas dunia agar mudah dipahami. Tujuannya adalah agar seseorang tersebut mudah membedakan dari fenomena tersebut manakah yang sah dan manakah yang masuk akal. ${ }^{10}$ Dengan demikian, integrasi sebagai paradigma akan digunakan untuk melihat eksistensi dan realita pemberlakuan K-13.

\footnotetext{
8 Asfiati, Pendekatan Humanis dalam Pengembangan Kurikulum (Medan: Perdana Publishing, 2016), hlm. 64.

${ }^{9}$ Waryani Fajar Riyanto, Integrasi-Interkoneksi Keilmuan: Biografi Intelektual M. Amin Abdullah (Yogyakarta: Suka Press, 2013), 767.

10 M.Q. Patton, Qualitative Evaluation and research Methods, C.A: Sage, Newburk Park, 1990 dalam Erlyn Indrti, Diskresi dan Paradigma, Sebuah telaah Filsafat Hukum, Pidato pengukuhan guru besar dalam Filsafat Hukum pada 
Dalam sejarahnya, upaya melakukan integrasi keilmuan dilatarbelakangi karena adanya dikotomisasi ilmu pengetahuan yang justru merugikan umat manusia. ${ }^{11}$ Dikotomisasi ilmu agama dan ilmu umum di Indonesia telah menyebabkan perkembangan ilmu pengetahuan tidak sehat dan juga menyebabkan ilmu agama tidak berkontribusi bagi umat manusia. Oleh sebab itulah integrasi keilmuan sangat diperlukan. Dalam perkembangan kajian integrasi keilmuan, sebenarnya terdapat banyak model integrasi keilmuan. Salah satunya adalah islamisasi ilmu. Proyek Islamisasi ilmu pengetahuan yang awalnya digagas oleh Naquib Al-Attas dari Malaysia dan kemudian diteruskan menjadi gerakan intelektual internasional dengan dipimpin oleh Ismail Raji Al-Faruqi dari lembaga pemikiran Islam internasional di Amerika Serikat menjelang 1980-an. ${ }^{12}$

Model lain adalah sebagaimana yang dikembangkan oleh Amin Abdullah dengan istilah integrasi-interkoneksi. Secara istilah, interkoneksi berarti menghubungkan beberapa hal. Jika dibandingkan dengan model integrasi yang lain, integrasiinterkoneksi termasuk model penyatuan keilmuan yang terbuka dan menghormati keberadaan jenis-jenis ilmu lain dengan tidak meninggalkan sifat kritis. ${ }^{13}$ Artinya walaupun terdapat penyatuan dari beberapa ilmu, identitas keilmuan masing-masing ilmu

Fakultas Hukum Universitas Diponegoro, Semarang pada 4 November 2010, hlm 15 .

11 M. Amin Abdullah, Islamic Studies di Perguruan Tinggi: Pendekatan Integratif-interkonektif (Yogyakarta: Pustaka Pelajar, 2012), hlm. 96-97.

12 Kuntowijoyo, Islam Sebagai Ilmu: Epistemologi, Metodologi, dan Etika (Yogyakarta: Tiara Wacana, 2006), hlm. 7.

${ }^{13}$ Riyanto, Integrasi-Interkoneksi ..., hlm. 715. 
tersebut masih kelihatan eksistensinya. Peleburan ini tidak benarbenar pelumatan menghilangkan sifat asli partikel keilmuan yang digabungkan. Setiap ilmu sekadar memberikan kontribusi karakteristiknya masing-masing untuk membentuk satu keterpaduan dalam tema tertentu.

Dalam pemberlakuan K-13, penggunaan paradigma integrasi interkoneksi ini sebenarnya sangat bisa dirasakan. Ini bisa dilihat terutama dalam pendidikan tingkat sekolah dasar. K-13 mengatur bahwa penyampaian materi untuk SD/MI menggunakan pendekatan tematik integratif dari kelas 1 sampai kelas VI. Pembelajaran tematik-integratif sering disebut dengan istilah pembelajaran terpadu atau integrated teaching and learning. Eksistensi pelaksanaan pembelajaran tematik-integratif dalam K-13 ini ditunjukkan dengan sistem pembelajaran yang memadukan satu atau beberapa mata pelajaran dari suatu pokok bahasan dan konsep tertentu ke dalam satu tema tertentu secara terencana. ${ }^{14}$

Dalam satu tema, materi yang disampaikan sebenarnya terdiri dari beberapa mata pelajaran. Pembelajaran tematik integratif dengan menggabungkan beberapa mata pelajaran berupaya mengintegrasikan berbagai kompetensi dari berbagai mata pelajaran ke dalam berbagai tema. Pengintegrasian tersebut dilakukan dalam kompetensi dan konsep dasar sekaligus. Dalam kompetensi, terdapat integrasi sikap spiritual, sikap sosial, keterampilan, dan pengetahuan. Sementara dalam konsep dasar, proses pembelajaran akan mengintegrasikan beberapa proposisi

\footnotetext{
${ }^{14}$ Subroto dan Herawati, Pembelajaran Terpadu: Materi Pokok PGSD (Jakarta: Pusat Penerbitan Universitas Terbuka, 2004), hlm. 19.
} 
dasar setiap mata pelajaran yang berkaitan dengan tema yang ditentukan. Keterpaduan dengan menggunakan tema ini akan menghubungkan satu persoalan dengan persoalan lainnya, sehingga keterpaduan tersebut akan membangun kesatuan (unity) pengetahuan. ${ }^{15}$

Alasan lain mengatakan bahwa pelaksanaan K-13 untuk tingkat sekolah dasar yang berprinsipkan tematik-integratif tersebut sesuai dengan paradigma integrasi-interkoneksi adalah sifat perpaduan (integrasi) beberapa materi pelajaran dalam satu tema tersebut bukan benar-benar melumat atau menghilangkan karakteristik mata pelajaran tersebut. Setiap mata pelajaran bisa dipertahankan karakteristiknya masing-masing sehingga kompetensi dasar dari setiap mata pelajaran dalam satu tema tetap dapat dibedakan dengan mata pelajaran lain. Perpaduan seperti inilah yang dimaksud dengan integrasi-interkoneksi, yakni model penyatuan keilmuan yang terbuka dan menghormati keberadaan jenis-jenis ilmu lain.

Melalui pola ini, aspek sikap/perilaku, keterampilan, dan pengetahuan dapat diperoleh secara komprehensif dan integratif dalam satu pokok tema pembahasan yang disampaikan dalam waktu dan proses belajar mengajar yang bersamaan. ${ }^{16}$ Inilah sekian landasan teoretis mengapa begitu urgensinya mengembangkan KD sikap spiritual dalam materi IPA Kelas VI. Meskipun materi IPA berkaitan dengan procces scientis, tetapi keberadaan spiritual tidak

\footnotetext{
${ }^{15}$ Hartono, Pendidikan Integratif (Purwokerto: STAIN Press, 2011), hlm. 57.

16 Suyanto dan Asep Jihad, Menjadi Guru Profesional: Strategi Meningkatkan Kualifikasi dan Kualitas Guru di Era Global (Jakarta: Esensi (Erlangga Group), 2013), hlm. 252.
} 
bisa diremehkan. Sesuai dengan karakteristik K-13, sikap spiritual juga harus ditanamkan kepada siswa sebagaimana kompetensikompetensi yang lain.

\section{Keterampilan Abad 21 dan Kurikulum 2013}

Pembicaraan mengenai keterampilan Abad 21 merupakan kajian yang luas. Sehingga, untuk memberikan indikator yang dimaksud tidaklah mudah. Beberapa pemikir dan stakeholders terkait, mempunyai konstruksinya tersendiri mengenai keterampilan Abad 21. Di antara dokumen berkaitan dengan isu tersebut adalah ATCS (assesment and teaching for 21st century skills). Dokumen ini dibuat gabungan Perusahaan Cisco, Intel and Microsoft dan telah launching di London pada acara Learning and Technology World Forum 2009. Dokumen itu sendiri disiapkan oleh Marilyn Binkley, Ola Erstad, Joan Herman, Senta Raizen, Martin Ripley with Mike Rumble. Mereka semua adalah para peneliti dan penulis internasional yang mempunyai kapasitas di bidang keilmuan masing-masing. ATCS menyimpulkan bahwa ada empat kelompok atas keterampilan Abad 21. Sayangnya indikator yang telah mereka buat tidak boleh dikutip karena alasan tertentu. ${ }^{17}$

Dokumen mengenai Keterampilan Abad 21 sebagai hasil kajian ahli yang tidak dilarang untuk dikutip adalah milik Partnership for 21st Century Skills. Tidak kalah dengan ATCS, beberapa member dalam Partnership for 21 st Century Skills adalah Adobe, Apple, at\&t, Blackboard, en@, intel, Lenovo, polyvision,

\footnotetext{
17 Marilyn Binkley dkk., Draft White Paper 1: Defining 21stCentury Skills, $\begin{array}{llll}\text { diakses } & 12 & \text { Mei } & \text { 2019, }\end{array}$ https://oei.org.ar/ibertic/evaluacion/sites/default/files/biblioteca/24_defining21 st-century-skills.pdf.
} 
Microsoft dan beberapa perusahaan internasional lain. Menurut mereka, keterampilan Abad 21 terbagi menjadi tiga kelompok. Pertama adalah keahlian berinovasi dan belajar yang mencakup berpikir kritis sekaligus memecahkan masalah, kreatif sekaligus inovasi dan komunikasi sekaligus kolaborasi. Kedua adalah keterampilan berkaitan dengan informasi, media dan teknologi yang meliputi literasi informasi, literasi media dan literasi ICT (Information, Communications \& Technology). Ketiga adalah keterampilan hidup dan karir yang meliputi fleksibilitas sekaligus adaptabilitas, inisiatif sekaligus self direction, keterampilan sosial sekaligus lintas budaya, produktivitas sekaligus akuntabilitas, kepemimpinan sekaligus responsibilitas. ${ }^{18}$

Tantangan keterampilan Abad 21 dalam penelitian ini tidak hanya dilihat sebagai target yang akan direspon melalui pelaksanaan K-13, tetapi juga khususnya keterampilan ini sebenarnya bisa digunakan untuk menghidupkan sikap spiritual dalam pembelajaran IPA. Alasan mengapa keterampilan Abad 21 justru harus digunakan untuk menghidupkan sikap spiritual adalah berlandaskan pada semangat K-13 itu sendiri. Dalam landasan teoretis dan filosofisnya, K-13 meniscayakan pencapaian integratif atas beberapa kompetensi sekaligus, yakni kompetensi sikap spiritual dan sosial, kompetensi pengetahuan dan kompetesi keterampilan. Di samping itu, upaya penajaman rasa sikap spiritual ini juga dalam rangka melaksanakan amanat perundang-undangan, yakni mengantarkan peserta didik mempunyai akhlak yang mulia.

\footnotetext{
${ }_{18}$ Partnership for 21st century Skill, 21stCentury Skills: How can you prepare students for the new Global Economy? (Paris: OECD/CERI, 2008), https://www.oecd.org/site/educeri21st/40756908.pdf.
} 
Merupakan sesuatu yang sangat memungkinkan untuk mengoperasionalkan keterampilan Abad 21 sebagai sarana implementasi sikap spiritual dalam pembelajaran IPA pada Kelas 6 Semester II. Hal ini bisa dilihat dalam beberapa kompetensi yang telah disusun oleh K-13 bagi pendidikan dasar tingkat sekolah dasar. Sebagai pembacaan awal, kompetensi pengetahuan dan ketrampilan IPA Kelas 6 dalam K-13 mencirikan pemenuhan kebutuhan keterampilan Abad 21 seperti memecahkan masalah karena pembelajarannya memerintahkan peserta didik untuk melakukan inkuiri. Kemampuan menanya mencirikan keterampilan Abad 21 untuk berpikir kritis. Mengasosiasi dalam mencirikan keterampilan Abad 21 untuk berkomunikasi. Bersikap ilmiah seperti kerjasama dan tanggungjawab mencirikan keterampilan Abad 21 untuk berkolaborasi. ${ }^{19}$

\section{HASIL PENELITIAN DAN PEMBAHASAN}

\section{Paradigma Integrasi Interkoneksi dan Pengembangan Kompetensi Dasar Sikap Spiritual}

SDIT Sunan Averroes adalah sekian sekolah dasar berbasis keislaman yang harus berinovasi dalam mengembangkan KD sikap spiritual dalam materi IPA Kelas 6. Sesuai dengan namanya, SDIT ini berbasiskan keislaman. SDIT Sunan Averroes berada di bawah Yayasan Nawesea. Selain lembaga pendidikan sekolah dasar, Yayasan ini juga

\footnotetext{
${ }^{19}$ Kementerian Pendidikan dan Kebudayaan, "Permendikbud Nomor 37 Tahun 2018 Tentang Perubahan Atas Permendikbud Nomor 24 Tahun 2016 Tentang Kompetensi Inti Dan Kompetensi Dasar Pelajaran Pada Kurikulum 2013 Pada Pendidikan Dasar Dan Pendidikan Menengah" (Kementerian Pendidikan dan Kebudayaan, 2018), hlm. 43.
} 
mempunyai Pesantren bernama Nawesea, Sekolah Menengah Pertama Sunan Averroes dan Taman Kanak-Kanak Islam Terpadu Sunan Averroes. Lembaga pendidikan ini didirikan oleh Prof. Drs. KH. Yudian Wahyudi, MA., Ph.D yang berada di Jalan Yogya-Wonosari KM 9 Dusun Sekarsuli, Desa Sendangtirto, Kecamatan Berbah, Kabupaten Sleman.

Dalam merespon dinamika regulasi K-13 tersebut, Guru Kelas VI SDIT Sunan Averroes menyadari bahwa tantangan yang dihadapinya tidak saja kesiapan materi serta sarana dan prasarana di sekolah. Salah satu guru yang ditemui, IW, memahami bahwa di antara tantangan tersebut adalah Permendikbud tidak memperinci KD sikap spiritual pada satu sisi dan pada sisi lain KD tersebut harus disesuaikan dengan tantangan kebutuhan keterampilan Abad 21. Dalam merespon tantangan tersebut, cara pandang yang integratif-interkonektif menjadi salah satu solusi untuk menginisiasi inovasi berdasarkan kemampuan sendiri.

Cara pandang integratif-interkonektif ini diterima IW dengan semangat menginovasi KD sikap spiritual. Berbekalkan paradigma integrasi-interkoneksi, IW meyakini bahwa sikap spiritual sama pentingnya dengan kompetensi pengetahuan dan keterampilan. Dia meyakini bahwa paradigma integrasi-interkoneksi merupakan sarana yang tepat untuk membantu menajamkan sikap spiritual dalam pembelajaran IPA. Ungkap IW, "Sesuai dengan semangat kelahiran paradigma ini yang tidak ingin mendikotomisasi 
ilmu agama dan ilmu umum, IW memahami bahwa paradigma ini bisa digunakan untuk menghidupkan sikap spiritual di tengah tuntutan pencapaian kompetensi pengetahuan dan ketrampilan dalam pembelajaran IPA kelas $6 " .{ }^{20}$

IW juga memahami bahwa integrasi sikap spiritual dengan keterampilan dan pengetahuan dalam pembelajaran IPA mempunyai arti penting sesuai dengan semangat yang dibawa dari kelahiran Sekolah Dasar Islam Terpadu Sunan Averroes. Sesuai namanya "Sunan Averroes" mempunyai semangat integrasi ilmu agama dan ilmu umum. Menurut keterangan pengurus Yayasan Nawesea diungkapkan yakni:

"Penamaan Sunan Averroes tersebut berangkat dari semangat menjaga tradisi keilmuan yang dibawa oleh Imam Ghazali dan Ibnu Rusyd. Bapak Pendiri Yayasan yang bernama Prof Drs KH Yudian Wahyudi menjelaskan bahwa Imam Ghazali adalah lambang pengembangan keilmuan keagamaan dalam pandangan ilmuwan muslim. Ini dikarenakan Imam Ghazali mempunyai karya kitab agama yang sangat banyak mulai dari fikih, usul fikih, tasawuf, filsafat Islam dan beberapa karya ilmu agama lain. Kecenderungan Ghazali yang berorientasi tasawuf tersebut dikembangkan oleh para wali di Indonesia. Mereka para wali tersebut bergelar Sunan di Indonesia. Oleh sebab itulah untuk melestarikan semangat ilmu keagamaan, nama Sunan digunakan dalam lembaga pendidikan ini. Untuk Averroes, nama latin ini diambil dari Ibnu Rusyd. Ini adalah tokoh ilmuwan Muslim yang tidak hanya telah melahirkan kitab berkaitan dengan hukum Islam. Ibnu Rusyd juga menghasilkan karya kitab berkaitan dengan ilmu kedokteran. Nama Averroes diambil sebagai lambang ilmu umum yang

20 Wawancara dengan Inne Wulandari Guru Kelas 6 SDIT Sunan Averroes,di SDIT Sunan Averroes., 25 April 2019. 
berorientasi kepada experimental scientis. Itulah sebabnya nama Sunan Averroes diambil sebagai lambang integrasi keilmuan antara ilmu umum dan agama. $^{21}$

Dalam batas tertentu, walaupun semangat keislaman dalam institusi sekolahnya sangat tinggi, IW juga menyadari bahwa penyertaan sikap spiritual dalam IPA Kelas 6 harus proporsional. Di sinilah IW menerapkan prinsip interkoneksi. Bahwasannya penyatuan sikap spiritual bersama dengan sikap sosial, kompetensi pengetahuan dan keterampilan pada satu materi IPA dalam satu tema; bukan berarti rasa pembelajarannya berubah menjadi pembelajaran keagamaan. Setiap kompetensi diberikan proporsinya masing-masing sesuai dengan karakteristik IPA. Artinya, penyatuan (integrasi) ini hanya dilakukan dalam batas sikap spiritual sekadar perlu dihubungkan (interkoneksi) dengan kompetensi pengetahuan dan keterampilan agar peserta didik tidak semakin meyakini ajaran agamanya ketika sudah menguasai dua kompetensi terakhir.

\section{Keterampilan Abad 21 Sebagai Implementasi Sikap Spiritual}

Salah satu strategi memanfaatkan keterampilan Abad 21 sebagai implementasi sikap spiritual adalah melakukan pembiasaan dan pemberian keteladanan dalam penyampaian materi di dalam kelas. Sebelum membahas strategi tersebut terlebih dahulu penulis perlu menjelaskan tema yang diajarkan

${ }^{21}$ Wawancara dengan Faiq Tobroni, pengurus Yayasan Nawesea, 26 April 2019 di Yayasan Nawesea. 
pada semester dua untuk kelas VI sekolah dasar. SDIT Sunan Averroes mengikuti perkembangan regulasi kurikulum 2013 yang terbaru, yang membagi temanya menjadi empat tema. Tema pertama adalah "Menuju Masyarakat Sehat". Tema ini mempunyai tiga Sub Tema, yakni: "Lingkungan Sehat, Masyarakat Sehat", "Masyarakat Sehat, Negara Kuat", dan "Membangun Masyarakat Sehat". Tema kedua adalah "Kepemimpinan". Tema ini mempunyai tiga sub tema, yakni: "Kepemimpinan di Sekitarku", "Pemimpin Idolaku”, dan "Ayo Memimpin". Tema ketiga adalah "Bumiku". Tema ini mempunyai tiga sub tema, yakni: "Perbedaan Waktu dan Pengaruhnya", "Bumiku dan Musimnya”, "Bumi, Matahari dan Bulan". Tema keempat adalah "Menjelajahi Luar Angkasa". Tema ini mempunyai tiga sub tema, yakni: "Keteraturan yang Menakjubkan", "Benda Angkasa Luar dan Rahasianya", “Tokoh Penjelajah Angkasa Luar".

Sebagai implementasi dari pandangan integrasi, empat tema di atas sebenarnya merupakan peleburan dari beberapa mata pelajaran, seperti Bahasa Indonesia, Ilmu Pengetahuan Alam, Ilmu Pengetahuan Sosial, Pendidikan Pancasila dan Kewarganegaraan, dan Matematika. Semangat integrasi dapat ditemukan dalam bentuk RPP-nya, yakni satu tema mencakup materi dari beberapa materi pelajaran. Sementara itu, semangat interkoneksinya dapat ditemukan dengan prinsip peleburan beberapa materi pelajaran dalam satu tema tersebut tidak dilaksanakan dengan sembarangan. Peleburan tersebut memperhatikan prinsip kesinambungan. Artinya, setiap materi 
dalam setiap pelajaran yang dileburkan memang mempunyai keterhubungan (interkoneksi) maksud dengan tema yang ditetapkan.

Pada mata pelajaran Ilmu Pengetahuan Alam, integrasiinterkoneksi materi dalam menyusun tema tersebut telah dikembangkan dengan menyertakan KD sikap spiritual. Uraian mengenai kompetensi inti dari kompetensi sikap spiritualnya adalah "menerima dan menjalankan ajaran agama yang dianutnya". Sementara uraian kompetensi dasarnya adalah "bertambah keimanannya dengan menyadari hubungan keteraturan dan kompleksitas alam dan jagad raya terhadap kebesaran Tuhan yang menciptakannya, serta mewujudkannya dalam pengamalan ajaran agama yang dianutnya”.

Dengan tema di atas, kompetensi dasar sikap spiritual yang bisa dikembangkan adalah dengan redaksi "bertambahnya keimanan peserta didik atas ajaran agama Islam dengan menyadari anugerah kesehatan hanya dari Allah SWT"; "bertambahnya keimanan peserta didik atas ajaran agama Islam dengan keteraturan hukum alam yang ada di bumi sebagai ciptaan Allah SWT"; dan "bertambahnya keimanan peserta didik atas ajaran agama Islam dengan menyadari keberadaan luar angkasa sebagai kebesaran ciptaan Allah SWT", ${ }^{22}$

Dalam proses pembelajarannya, tampak guru mengidentifikasi beberapa kata kunci keterampilan Abad 21

22 SDIT Sunan Averroes, Rencana Pelaksanaan Pembelajaran Kelas 6 SDIT Sunan Averroes (Yogyakarta, SDIT Sunan Averroes, 2019, dokumen tidak diterbitkan) 
yang harus ditonjolkan dalam proses pembelajaran untuk mengoperasionalkan $\mathrm{KD}$ di atas. Sebagai contoh ketika berbicara mengenai tema "Menuju Masyarakat Sehat". Pada materi tentang ciri-ciri pubertas pada anak laki-laki dan perempuan, guru membiasakan siswanya untuk berdiskusi dalam rangka mengidentifikasi dan menjelaskan ciri pubertas pada anak sesuai jenis kelaminnya. Diskusi diawali dengan membaca "basmalah" dan selesai mengucap "alhamdulillah". Begitupula ketika berbicara mengenai jagad raya, guru mengarahkan muridnya untuk mengucapkan "subhanallah" dan mendalami makna itu semua sebagai tanda kebesaran Allah. ${ }^{23}$

Sementara penekanan untuk keterampilan abad 21 bisa ditemukan dengan minimal memenuhi indikator critical thinking. Sebagai salah satu keterampilan abad 21, berpikir kritis ini sering ditekankan kepada peserta didik untuk memperkuat kompetensi spiritualnya. Cara yang ditempuh guru adalah menyisipkan pertanyaan "who is creator behind the reality?". Seperti dalam kajian perkembangan pubertas pada laki-laki dan perempuan. Maka dalam hal ini, untuk memperkuat keimanan, guru menyisipkan pertanyaan siapa yang menciptakan perubahan fisik pubertas pada anak laki dan perempuan tersebut. Jawabannya adalah Allah. Guru menjelaskan bahwa manusia tinggal menikmati dan mensyukuri tubuhnya, sementara Allah-lah yang menyempurnakan penciptaannya. Ini merupakan doktrin tersengaja untuk memperkuat keimanan seseorang. 
Begitu pula dalam materi tentang benda luar angkasa. Ketika terdapat penjelasan mengenai perputaran benda-benda luar angkasa seperti bintang dan planet lain yang tidak menabrak bumi atau saling bertabrakan, guru menyisipkan pertanyaan mengapa hal itu bisa terjadi? Jawabannya adalah karena itu merupakan ciptaan Allah yang Maha Sempurna. Kemudian penjelasan ilmiahnya karena benda-benda tersebut sudah mempunyai garis edarnya.

\section{SIMPULAN}

Paradigma keilmuan memang merupakan aspek yang penting bagi pendidik. Paradigma tersebut akan menjadi pendorong baginya untuk menentukan sikap dalam menghadapi masalah yang dihadapinya. Kemampuan guru SDIT sunan Averroes untuk menginovasi KD sikap spiritual dalam materi IPA tidak lepas berkat kecerdikan guru tersebut mengelola paradigma integrasiinterkoneksi. Kebutuhan mengembangkan KD sikap spiritual dalam materi IPA Kelas 6 SDIT Sunan Averroes sebenarnya tidak hanya didukung semangat keilmuan gurunya yang bisa memaknai paradigma integrasi-interkoneksi, tetapi juga didukung dengan sejarah pendirian institusi itu sendiri. Dengan mengambil nama Sunan Averroes, semangat yang dibawa lembaga pendidikan ini adalah mengusung semangat revitalisasi ilmu agama yang telah dikembangkan oleh para Sunan di bumi nusantara sekaligus pengembangan ilmu umum experimental scientis yang telah dikembangkan oleh para ilmuwan muslim seperti Ibnu Rusyd (Averroes). 
Penggunaan keterampilan Abad 21 sebagai implementasi sikap spiritual telah disusun dalam RPP. Strategi yang digunakan adalah dengan cara menyisipkan pertanyaan siapakah Pencipta dari segala eksistensi dan peristiwa alam tersebut. Jawabannya adalah Allah sebagai Tuhan umat Islam. Dengan menanya Pencipta, sebenarnya guru sedang mengasah salah satu keterampilan Abad 21, yakni critical thinking. Pertanyaan tentang Pencipta eksistensi dan persitiwa kejadian alam ini mendorong peserta didik untuk berpikir kritis. Selanjutnya kemampuan berpikir kritis tersebut dikembangkan dengan penjelasan atas eksistensi dan peristiwa alam tersebut berlandaskan hukum dan prinsip dalam Ilmu Pengetahuan Alam. Dengan demikian, susunan RPP tersebut tidak sekadar memperkuat aspek koginitifnya tetapi juga aspek spiritualnya. Dalam bahasa agamanya, guru mengantisipasi agar materi yang disampaikan tidak menyebabkan peserta didiknya termasuk golongan yang ketika mendapatkan pengetahuan justru jauh dari hidayah Allah.

Penelitian ini sebenarnya bisa dikatakan sebagai penelitian pembuka untuk lebih lanjut melihat bagaimana upaya guru SDIT Sunan Averroes dalam merespon kebutuhan keterampilan abad 21. Penelitian ini hanya mengambil posisi melihat respon tersebut untuk mengembangkan $\mathrm{KD}$ sikap spiritual dalam tataran pembuatan RPP. Penelitian selanjutnya bisa melihat bagaimana RPP yang telah dibuat, apakah bisa dilaksanakan oleh guru selama proses pembelajaran sehingga peserta didiknya benar-benar memiliki kompetensi sebagaimana dikehendaki. 


\section{E. DAFTAR PUSTAKA}

Abdullah, M. Amin. Islamic Studies di Perguruan Tinggi: Pendekatan Integratif-interkonektif. Yogyakarta: Pustaka Pelajar, 2012.

Asfiati. Pendekatan Humanis dalam Pengembangan Kurikulum. Medan: Perdana Publishing, 2016.

Hartono. Pendidikan Integratif. Purwokerto: STAIN Press, 2011.

Kementerian Pendidikan dan Kebudayaan. "Permendikbud Nomor 37 Tahun 2018 Tentang Perubahan Atas Permendikbud Nomor 24 Tahun 2016 Tentang Kompetensi Inti Dan Kompetensi Dasar Pelajaran Pada Kurikulum 2013 Pada Pendidikan Dasar Dan Pendidikan Menengah." Kementerian Pendidikan dan Kebudayaan, 2018.

. Permendikbud Nomor 67 tahun 2013 tentang KD dan Struktur Kurikulum SD-MI. Jakarta: Kementerian Pendidikan dan Kebudayaan, 2013.

Kunandar. Penilaian Autentik (Penilaian Hasil belajar Peserta Didik berdasarkan Kurikulum 2013). Jakarta, Indonesia: PT. Raja Grafindo Persada, 2014.

Kuntowijoyo. Islam Sebagai Ilmu: Epistemologi, Metodologi, dan Etika. Yogyakarta: Tiara Wacana, 2006.

Marilyn Binkley, Ola Erstad, Joan Herman, Senta Raizen, Martin Ripley, dan Mike Rumble. Draft White Paper 1: Defining 21stCentury Skills. Diakses 12 Mei 2019. https://oei.org.ar/ibertic/evaluacion/sites/default/files/bibliot eca/24_defining-21st-century-skills.pdf.

Menteri Pendidikan dan Kebudayaan Republik Indonesia, Perubahan Atas Permendikbud Nomor 24 Tahun 2016

Tentang Kompetensi Inti Dan Kompetensi Dasar Pelajaran Pada Kurikulum 2013 Pada Pendidikan Dasar Dan Pendidikan Menengah, Peraturan Menteri Pendidikan dan Kebudayaan Republik Indonesia No. 37 Tahun 2018, Ditetapkan 14 Desember 2018.

Miles, Metthew B dan A Michael Huberman. Analisis Data Kualitatif. Buku Sumber tentang Metode-Metode Baru. Jakarta: UI Press, 1992.

Natabaya, H.A.S.. Sistem Peraturan Perundang-Undangan Indonesia. Jakarta: Sekretariat Jendral Mahkamah Konstitusi, 2006. 
Patton, M.Q.. Qualitative Evaluation and research Methods. C.A: Sage, Newburk Park, 1990.

Partnership for 21st century Skill. 21stCentury Skills: How can you prepare students for the new Global Economy? Paris: OECD/CERI, 2008. https://www.oecd.org/site/educeri21st/40756908.pdf.

Redhana, I Wayan, "Mengembangkan Keterampilan Abad Ke-21 Dalam Pembelajaran Kimia”, Jurnal Inovasi Pendidikan Kimia, Vol 13, No 1, 2019, halaman 2239 - 2253.

Riyanto, Waryani Fajar. Integrasi-Interkoneksi Keilmuan: Biografi Intelektual M. Amin Abdullah. Yogyakarta: Suka Press, 2013.

Subroto dan Herawati. Pembelajaran Terpadu: Materi Pokok PGSD. Jakarta: Pusat Penerbitan Universitas Terbuka, 2004.

Sugiyono. Metode Penelitian Kuantitatif dan Kualitatif. Bandung: Alfabeta, 2009.

Suyanto dan Asep Jihad. Menjadi Guru Profesional: Strategi Meningkatkan Kualifikasi dan Kualitas Guru di Era Global. Jakarta: Esensi (Erlangga Group), 2013.

Wawancara dengan Faiq Tobroni, pengurus Yayasan Nawesea, 26 April 2019 di Yayasan Nawesea.

Wawancara dengan Inne Wulandari, Guru Kelas 6 SDIT Sunan Averroes, 25 April 2019 di SDIT Sunan Averroes. 